\title{
Top projects suffer as medical funding falters
}

Natasha McDowell, London

British biologists funded by the Medical Research Council (MRC) are facing shortfalls in cash, after investment in a series of new projects has left the council unable to award grants to many top-ranked projects, Nature has discovered.

The MRC, which distributes British government funds for medical research, generally provides money for all projects given the top alpha-A rating by the council's peer-review board. But at a meeting last month, the council decided not to fund 36 alpha-A projects, and to delay funding for a further three. Forty-five alpha-A projects received funding. "It has been a difficult year for applicants and we are sorry not to have been able to fund more," says George Radda, the MRC's chief executive. It is likely that funding will be tight next year, he adds.

An MRC spokesperson says that the shortage is due to the council's investment in large new projects such as the UK Biobank, a database of the genetic details of half a million British people. The $\mathfrak{E} 45$ million (US\$69-million) project, which was launched in April, is funded by the MRC together with the Wellcome Trust and the Department of Health. The data will be stored alongside medical records and lifestyle information, and will be made available to both academic and commercial groups.

Such projects have the backing of many
British researchers, but those who have been denied funding are angry at the way the MRC has managed the situation.

"It's extraordinary that they have let it happen," says one researcher, whose fiveyear programme grant, which covers salaries for postdocs, research assistants and lab supplies, was not renewed despite being awarded the top peer-review ranking. "They should have made sure they had enough money to fund all the alpha-As. The message it sends out abroad, to potential postdocs, is that UK funding is fickle, irrespective of the quality of the science."

Researchers who have not been granted funds are also disgruntled at being left in the dark about why they missed out. The council ranks alpha-A projects and uses the results to decide which to fund, although these rankings are not released. A decision to delay decisions on a previous batch of alpha-A applications, made at an MRC meeting last October, has angered applicants further. Some researchers were reassured at the time at receiving alpha-As, only to be denied funding nine months later.

"The message it sends out to young researchers is that there is no job security and no future in research," says another MRC-funded researcher.

Many researchers contacted by Nature say they are worried that university research groups could be particularly vulnerable. The MRC has other funding commitments, such

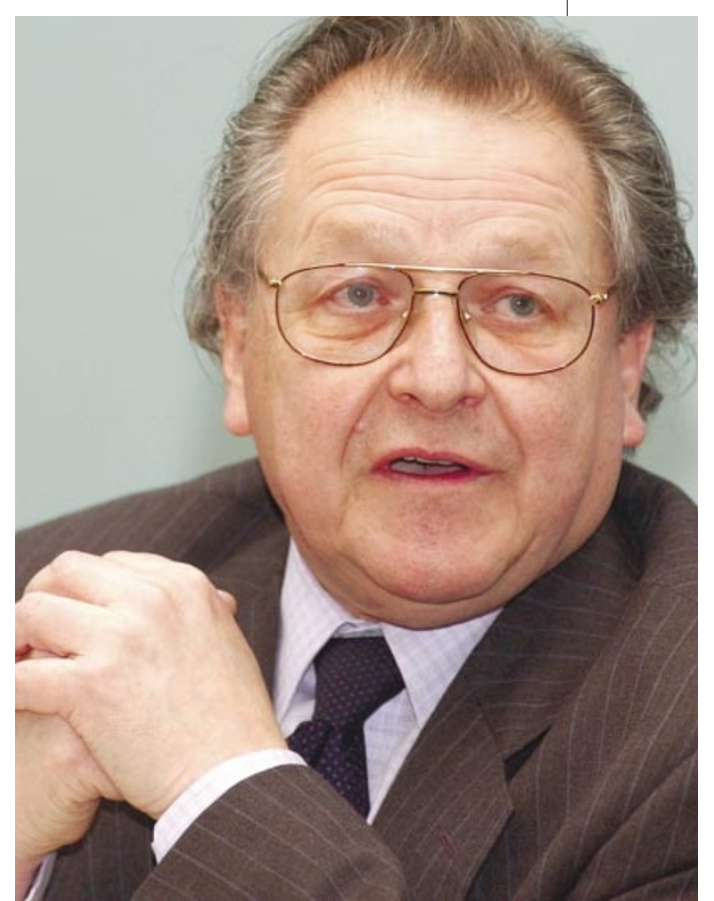

MRC head George Radda says the council regrets having been unable to fund more projects.

as salary costs, at the various research centres that it runs. The MRC says it cannot provide details on which projects have been funded, but stresses that all decisions were based on scientific merit.

www.mrc.ac.uk

\section{Lessons in research aim to win pupils over to science}

\section{Quirin Schiermeier, Bremerhaven}

For 22 schoolchildren in the north German seaside town of Bremerhaven, the new school year has begun in unusual fashion. Every Tuesday and Thursday, they swap their classrooms for lecture theatres and labs at the Alfred Wegener Institute for Polar and Marine Research (AWI) on the coast of the Wadden Sea.

There they are taught biology, chemistry, physics, mathematics and English. The lessons bear little resemblance to the way that German 16-18-year-olds are usually taught science. No school bells interrupt the day-long projects; theoretical classes and practical sessions are closely intertwined; and there are no fixed timetables. Guided by science teachers and AWI researchers, the pupils will, over the next three years, learn the principles of scientific experimentation and how to use research equipment by carrying out field research and lab work on their own.
The scheme is the most ambitious of a recent series of attempts to stem the decline in the number of students choosing science at school and university. Some German universities and research institutes are already offering taster courses and internships for schoolchildren, but the AWI's attempt to integrate science education into the day-to-day work of a research institute is the first of its kind in the country.

The students will learn basic techniques in Earth sciences, such as how to test for the presence of various substances in water samples. They will then apply these to their first project - a study of the Wadden Sea ecosystem. The area is Europe's largest coastal wetland, flooded at high tide and dry at low tide.

AWI researchers have promised to do their best to support the scheme. "Once the students master the basic mathematical and scientific tools of the trade, there are many ways to let them participate in research work," says AWI oceanographer Ulrich Bathmann. Bathmann has compiled a list of possible teaching topics, including carbon cycles, species diversity in phytoplankton and atmospheric processes.

Science education experts are enthusiastic about the idea of bringing schools and research centres closer together. "This is an exciting new approach," says Dagmar Schipanski, science minister of Thuringia and president of the German conference of education ministers. "Since reunification, I have observed the decline of young people's interest in science with great concern."

A few similar schemes have been run in Denmark and the United States. And Walter Kröll, president of the Helmholtz Association of National Research Centres, to which the AWI belongs, plans to extend the project. "Teaching laboratories similar to the AWI's will be created at all Helmholtz centres," he says.

| www.awi-bremerhaven.de/index-e.html 